\title{
Uses and Abuses of Creativity. Sociology of creative processes, transitions to digital and creative policies
}

Juan Arturo Rubio-Arostegui

UNIVERSIDAD ANTONIO DE NEBRIJA

jrubioåanebrija.es

Juan Pecourt

UNIVERSITAT DE VALÈNCIA

juan.pecourtauv.es

\section{Joaquim Rius-Ulldemolins}

UNIVERSITAT DE VALÈNCIA

joaquim.rius@िuv.es

Received: 14/05/2016

Accepted: 1/11/2016

\begin{abstract}
Creativity is a notion awakening growing interest in the social sciences. This attention mirrors the debate on the potential economic and social development of creativity as a skill, profession or industry. However, there is also rising critical interpretation of the abuse of this concept, exploited to legitimize the hasty digitization of the cultural field, and of the instrumentalization of culture in pursuit of economic interests. This article is grounded on the contributions of numerous sociologists (Bourdieu, Collins and Menger) in an attempt to reconsider the conditions under which creativity develops, and examine how the framework of digitalization and instrumentalization is shifting (not always positively) the structure of this field, and the interaction frameworks that favour the development of this creation of culture.
\end{abstract}

Keywords: creativity, cultural policy, digitalization, white elephants

Corresponding author: Juan Arturo Rubio-Arostegui. Universidad Antonio de Nebrija, Madrid. Facultad de Artes y Letras. Campus de La Berzosa: c/ del Hostal, 28240 Hoyo de Manzanares (Madrid).

Suggested citation: Rubio, A., Pecourt, J, Rius-Ulldemolins, J. (2016). Uses and Abuses of Creativity. Sociology of creative processes, transitions to digital and creative policies. Debats. Journal on Culture, Power and Society, 1, 123-142. 


\section{INTRODUCTION}

The debate surrounding creativity (its origin, its uses and its effects) has become a main focus of controversy in the social sciences. This is due to a number of factors such as the growing role of the so-called cultural and creative industries in the field of production and consumerism. But it is also due to the very power of creativity as a discourse in itself which, like a liquid resource, is imbued with educational discourses based on new didactics and the central role of student learning, or with the management of personality aptitudes and emotional intelligence, besides expert knowledge, to survive in the labour market, to give but a few examples.

From our point of view, debates surrounding creativity take a substantivist position on this, and ignore or overlook the social conditions under which it arises and develops, on the one hand and, on the other, the niches and potentiality of this discourse beyond its role in the arts and cultural industries. Furthermore, the celebratory position on creativity as a formula for solving the problems of post-Fordism societies overlooks the potential destructuring effects of this discourse. Above all, when it interrelates and merges with other prevailing discourses, such as educational discourse, as we have just pointed out, or others such as management or innovation (Alonso and Fernández Rodríguez, 2013) and its effects on some transformation processes to digital culture. Here, we are going to show that these discourses on creativity have been abused or «hijacked» in order to design and legitimize creative projects, infrastructures, events or clusters. Projects that contemplate the social conditions under which creativity develops as those that establish the main contributions of the sociology of creativity.

In the first part of this article we will undertake the analysis of the sociological study of creativity and the production of cultural value, which is approached from different viewpoints. On the one hand, the Durkheimian view, which is centred on the configuration of institutionalized rites that contribute to focusing symbolic interest (Collins, 2009) and, on the other hand, the Weberian view, which analyses the social configuration of genius (Menger, 2010). In this work we will take ideas from both views, paying special attention to the contributions of Bourdieu and Collins, who follow in the wake of Durkheim, and of Menger, who is closer to the Weberian position. In the second part of the paper, we will contrast the main theses of sociological analysis with notions about transition to the digital world. In this sense, a critique will be made of cyber-utopian discourse, which advocates the benefits of our $21^{\text {st }}$ century digital culture. And finally, we will analyse how the discourse on creativity has permeated territorial development and has led to the undertaking of large projects we could call «cultural white elephants».

\section{CONCEPTIONS OF CREATIVITY AND SOCIOLOGICAL PERSPECTIVE}

In highly diverse currents of thought, creativity is considered an essential attribute of action and a necessary, if not indispensable, condition influencing social change. However, in defining their basic characteristics, the differences between schools and disciplines are so striking that they seem to refer to different spheres of human experience. For example, in ancient traditions, from classical Greece to the Middle Ages, creativity was associated with spiritual and mystic beliefs (Runco and Albert, 1999). Creativity was believed to be a divine and supernatural reality, a manifestation of God or an exceptional quality that God bestowed upon certain chosen individuals. The Greek concept of tejné is transformed into the creationist-medieval culture, stripping it of man to become an utterly divine property. Classical Greece emphasized the metaphysical source of all creative achievement and believed in the existence of the individual daimon, a sort of spirit that guided the act of creation (Misztal, 2009). During modernity, the advent of the concept of individual, the process of secularization that begins with philosophical modernity (Descartes), among other factors, brings new ways of treating creativity and reintroduces creative activity in man, associated with man's capacities and his talent (English empiricism and German idealism — Kant and Schelling). In more recent times, emphasis has been placed on the importance of creativity and 
originality as a fundamental element of economic development and the construction of personal identity. Indeed, for some, it does not depend on a talent or special gift, but originates in a specific mental state of the human mind (Bohm, 2006). This implies that such a creative mental state is not exclusive to a select minority, but can be achieved by anyone who has the required preparation and who uses the right techniques. Nonetheless, despite their apparent diversity, all these fundamentally Western traditions have in common the link between creativity and innovation. In other words, they affirm the capacity of the human being to produce something out of nothing, owing to the influence of an exceptional and mysterious power, or the aptitude of the human mind to come up with unprecedented and unexpected solutions.

The concept of creativity did not gain importance until the twentieth century, both in terms of philosophical discourse and social sciences in general, especially in psychology and pedagogy. Likewise, sociology has been too timid to deal with understanding the mystery or «black box» of creativity. The attention paid to studying large social structures and processes of change, the main approach to the rational and normative action of the individual, have left little room for a detailed reflection on creativity (Joas, 1996). However, while this notion, unlike others, has failed to acquire a central role in what we might call classical sociology, it has stimulated relevant debates that are gaining prominence. In this work, we start from the premise that sociology has highly valuable tools to gain insight into the social origins of creativity and the forms of valorization imposed upon it.

\section{THE NOTION OF CREATIVITY IN SOCIAL SCIENCES}

During the Enlightenment, the recognition of the power of reason and the increasing importance of empirical verification reversed the traditional discourse on creativity, thereby engendering new interpretative models in which social sciences played a fundamental role. A discussion of the complex debates generated by the idea of creativity falls outside the scope of this work, therefore we will limit ourselves to identifying some of the main currents of thought and then examine contemporary sociological contributions, focusing on the works of Pierre Bourdieu (2002), Randall Collins (2009) and Pierre-Michel Menger (2010).

Broadly speaking, we can identify, on the one hand, the humanistic interpretation of creativity based on the romantic ideal that emerged in the nineteenth century and on the notion of individual genius (Herder, Fichte, Schelling). Creative individuals are geniuses, usually ahead of their time and misunderstood, whose contributions will only be understood by the generations to come. The romantic conception of creativity, which revolved around the idea of individual genius, has greatly influenced the West and has impregnated the debates of the nineteenth and twentieth centuries on the subject. In view of this humanistic conception, the social sciences have made diverse contributions to our understanding of creativity from the philosophy of science (Popper, Kuhn, Lakatos), sociology of science (Merton, Latour) and sociological pragmatism (Pierce, Mead, Dewey). The scientific discourse of creativity arose within the discipline of psychology in its different currents (mainly social psychology and cognitive psychology) during the twentieth century, during which time different approaches were adopted to endeavour to measure variables and find a relationship between creativity and intelligence, giftedness and personality traits. However, during that century there was a tendency whereby the focus on the individual was extended to other social variables in an attempt to explain creativity, (Rubio Arostegui, 2013).

An important author greatly influencing the scientific production of creativity from an ecological approach to psychology is Csikszentmihalyi (1988), who stresses the impact of the social environment on individual creativity. Thus, he describes creativity as the result of the interaction between culture, the person who brings novelty to the symbolic field and an environment of legitimation composed by experts endowed with symbolic capital, who label and recognize innovation. 
More recently sociology has made important contributions that take elements of the aforementioned traditions to challenge the romantic conception of creativity. Instead, it emphasizes the importance of social conditions that favour creativity and the forms of social valorization that cause certain actions to be considered as creative while others are discarded. The most recent outstanding contributions are the works of Pierre Bourdieu and Randall Collins, which we will deal with in detail below.

\section{Creativity in the cultural fields: the contribution of Pierre Bourdieu}

Bourdieu's (2002) sociological conception of creativity is based on the dynamics of cultural fields and on the various expressions adopted by the individual habitus within. Creativity as an original artistic or academic novelty would be defined in terms of the dialectical process taking place in the artistic fields. Thus, Bourdieu understands the fields of interaction as structured spaces, comprising a limited set of social positions (which can be presented as individuals, groups, organizations, etc.) that compete for a specific resource that the French author calls capital. As the resources provided by the fields are scarce and, therefore, not all players can accumulate them in sufficient quantities, there is a tendency for these resources to be monopolized in the hands of a few (Bourdieu, 2008). Within the various fields that make up social life, Bourdieu identifies a cultural field characterized by the presence of a specific type of agent (artists, writers, actors, etc.) competing for the specific resource offered by this space. This is the so-called cultural capital, as well as symbolic capital. Cultural capital comprises the knowledge, skills and competences that the individual accumulates over time, while symbolic capital is the recognition and prestige attained.

Bourdieu assumes that a proper life trajectory and socialization, associated with the history of the cultural field, are required in order to be creative or, more specifically, for the creations themselves to be recognized as such within the cultural field. It is also necessary to possess certain symbolic resources that provide insight into the true problems and the authentic spaces where creativity is found. Creativity is the result of conflict and competition between individuals and groups (schools, movements, associations, etc.) which thus try to mobilize their respective cultural capital and gain recognition from the community. These conflicts imply the existence of two large groups: a) dominant positions, i.e., those that are widely recognized by the artistic community and tend to control the specific game rules in the field (imposing styles, themes, issues, etc.), and b) dominated positions, occupied by players who have not achieved recognition within the field, because they have neither the right socialization nor the necessary resources to act in it. Bourdieu considers that the real prospects of innovation in the latter group are very scarce. Indeed, their structural limitations, both materially and mentally, will impose a repetitive and imitative logic on their actions, with no real capacity to propose innovative ideas that can transform the game rules of their cultural field. This basic premise of Bourdieu's theory clashes with many current perspectives that proclaim and celebrate the universality of creativity.

If dominated positions lack real prospects of making creative contributions in the cultural sphere, they will be restricted to what happens in the domain of dominant positions. Bourdieu's view on this point is rather nuanced: dominant positions do not form a homogeneous set of players with common interests. We can identify two competing poles within the dominant players: on the one hand, established players, those who have a long trackrecord in the cultural field and who, in their day, made some kind of symbolic revolution that placed them in a position of power. Over time these players have established their dominance by imposing the specific game rules that determine the functioning of the field (for example, when a particular historical moment witnesses the imposition of the realist novel or pictorial expressionism). On the other hand, we have the contenders, that is to say, those players who do not have the decision-making power of the established players, but who have a suitable trajectory 
and enough capital to propose alternatives to the cultural establishment. Generally, the clash between the established players and the contenders takes the form of a generational conflict, where young people try to create their own space or even impose a symbolic revolution to change the game rules and place themselves in more influential positions. These struggles between social groups underlie the struggles between tradition and avant-garde, classical and modern, etc., in which creative innovations (Impressionists, Surrealists, Dadaists, etc.) emerge. Although the established players have adequate resources, Bourdieu does not consider them to be the most creative collective, because their interests lead them to maintain the status quo and prevent potential transformation. In contrast, the interests of contenders are directly associated with the renewal of the cultural field, so they will be more likely to make creative contributions (which are reflected in the emergence of new philosophical schools, new artistic movements or literary styles, etc.).

However, although contenders tend to be creative and commonly spark many of the revolutions that occur in the artistic and literary fields, they often find their prospects of action weighed down by their subordinate position with respect to the consecrated. Consecrated persons, as we have seen, tend to conservatism, dominate cultural institutions and are not very interested in change or novelty. However, among the consecrated, and in a setting of fully autonomous cultural fields free of the shackles of economic and political power, a specific type of creative player may arise that Bourdieu calls the consecrated heretic. In other words, those individuals who hold a dominant position in the cultural field and are able to impose styles and trends, as well as act as gatekeepers, while simultaneously transcending their specific interests (their temporary interests) to exercise a universalist action based on «interest in disinterest», which gives rise to «art for the sake of art» or «knowledge for the sake of knowledge» (Bourdieu, 2008). Within this select group of consecrated persons, their habitus and their specific dispositions will lead them to be creative and to propose constant transformation of the field, sometimes in accordance with the interests of the contenders, who can adopt them as teachers or examples to follow.

\section{Creativity and interaction rituals: Randall Collins' contribution}

From the sociological perspective, a second contribution to our understanding of creativity comes from the American sociologist Randall Collins (Collins, 2005, Collins, 2009). Whereas Bourdieu focuses on the role of large social structures (in the fields of interaction) and the interiorization and reproduction of these structures by individual agents, Collins presents a microsociological vision focusing on the role of faceto-face relationships and the rituals that shape social relations in the realm of everyday life.

In agreement with the French author, Collins asserts that creativity is related to the possession of specific resources, although he specifically refers to two: cultural capital and emotional energy. The idea of cultural capital is taken from Bourdieu and, therefore, has a similar meaning to that explained above, although sometimes he refers to it as symbols of group membership, emphasizing its capacity to forge the individual's identity and to integrate him/her into a specific social group. For his part, through the idea of emotional energy, Collins alludes to the central role of emotions in the creative individual. Thus, among the resources available for action, there are not only economic or cultural resources, but also emotional resources (which reflect moods such as joy, sadness, hatred, enthusiasm or resentment) and lead to different ways of acting within the social reality.

The artistic, philosophical, scientific or literary communities are organized according to the manifold interactions that their members perform, and wherein cultural and emotional capitals are distributed. Collins asserts that interactions taking place in cultural settings are structured around specific rituals and that these rituals determine the individual's ability to gather symbolic and emotional resources, enabling him/her to be creative and occupy a relevant place within the cultural field. Rituals of interaction are important for 
two main reasons: a) they provide a common focus for the whole artistic or literary community, i.e., they enable community members to focus on the same issues and problems, and $b$ ) bestow a common state of mind upon the community, which is reflected in the interest and enthusiasm for the objects and topics dealt with in these areas (Wittgenstein's philosophy, Schubert's music, Jackson Pollock's painting, etc.). The common focus of attention and common emotional energy give rise to «sacred objects», which can be ideas, words, images or sounds. Such objects are honoured by the community as a whole, and acquire an aura that is preserved thanks to the rituals organized around them (lectures, classes, concerts, visits to museums, etc.), which bestow value upon them.

The fact that ritualized interactions are decisive in boosting individual creativity imposes important constraints. In the first place, those individuals who do not form part of the rituals will not have much chance of being creative or, at least, of being recognized as creative people. They will not have gathered the appropriate cultural and emotional resources that enable them to make impactful contributions able to draw the attention of the whole community concerned. Also, forming part of the collective interactions does not ensure creativity: rituals impose stratification on participants and grants dual-structured spaces formed by a centre and a periphery. On the periphery, most participants contribute in a minor or intermittent way, have few cultural and emotional resources and, therefore, very few opportunities to make really creative contributions. These groups will tend to develop negative emotions regarding their situation and performance (sadness, depression, professional meaninglessness, artists' block, etc.), which will curb their creative options. Furthermore, their limited control of cultural capital will mean that they are somewhat unaware of where the most innovative trends lie at any given moment. By contrast, in the centre of the sphere we find the really influential minority, those who have the right cultural and emotional resources and tend to be enormously creative. These individuals, thanks to their successes, will tend to accumulate positive emotions (ambition, enthusiasm, job security, professional satisfaction and fulfilment, etc.), which will boost their creative power and maintain their privileged position. Their domination of cultural capital will determine that they are, almost always, on the most innovative fronts, where true creative contributions arise.

According to Collins, the creative individual needs specific resources, but the creative act itself is collective and social, and it emerges and flourishes with interaction among equals, with strategic positioning within specialized rituals being determinant. The idea of the lonely and forgotten genius who lives in a loft composing an advanced masterpiece that only future generations will understand is, according to Randall Collins, a romantic myth that does not portray how these spheres actually work. This author affirms that the great cultural innovations have come about within communitarian dynamics, in which a host of people interacted around common «sacred objects». In this respect, necessary conditions of creativity include the relationship between teacher and disciple, and contact with the most productive and renowned representatives in the field.

Rituals of interaction play an essential role in stratifying artistic and literary communities, since they allow interactions to be fruitful and meaningful. Like Bourdieu, Collins asserts that originality and innovation are minority realities and that very specific conditions have to arise for them to flourish. In fact, this author suggests the existence of the «law of small numbers», a kind of iron law that determines creative potential in any cultural field (1987). The American sociologist fixes this number allowing for the emergence of really creative exchanges to be between three and six. A smaller number would greatly limit the possibility of exchange and would not foster the conflict from which creativity emerges, while a higher number would defocus the centre of attention and would not allow the existence of common spaces that would foster meaningful interactions. Again, as in Bourdieu's case, we see that Collins questions certain current visions that celebrate the democratization of creativity and its extension to the population as a whole. 
Valuation actions and institutional selection mechanisms: Pierre-Michel Menger's contribution

The French sociologist Pierre-Michel Menger's contributions fall within the Weberian current that analyses the social configuration of genius (Menger, 2009). Certainly, other authors have worked on the social analysis of creative genius, such as the cases of Mozart (Elías, 2002), Beethoven (DeNora, 1995) or Van Gogh (Heinich, 1992). They emphasize the social determinants underlying these creators' creativity, and the construction of their artistic career and struggle (in some cases successful and in others frustrated) to attain autonomy in their creation and artistic legitimacy, without other factors (religious, political or commercial) influencing the response to their work. Therefore, these studies emphasize the perspective of charism as a social product, wherein the creation of cultural value stems from recognition.

However, beyond these socio-historical analyses, from a more meso-sciological perspective, Menger (2009) introduces the analysis of the everyday recognition processes which take place by two mechanisms. 1) The continuous acts of appraisal that the medium itself undertakes, whereby small differences in talent are considered essential and generate great distances in reputation. Such support provides better learning options (access to scholarships, training institutions or artistic projects, which constitute a fundamental learning mechanism, learning from practice). Also, greater recognition provides greater security and protection against failure, which in turn encourages innovative capacity, thus closing a virtuous circle. 2) There are formal institutional and market selection mechanisms, which pave the way towards recognition and learning among the elite, and promote a massmedia reputation, generating a mechanism similar to the winners take all, whereby a small elite possesses all the reputation indicators (Menger, 1999).

Thus, all these analytical systems emphasize the importance of interactions in creation, recognition and value setting. Therefore, we must consider whether certain cultural systems favour the generation of cultural value more than others, and whether there may be developments or dysfunctions of the cultural system that diminish the capacity to generate creativity of the cultural system. This question acquires maximum relevance when considered within the context of the digital transition of culture.

\section{THE DIGITAL TRANSITION AND RHETORIC OF CREATIVITY UNDER THE AUTHORS' SOCIOLOGICAL ANALYSIS: STRUCTURES, INTERACTIONS AND CREATIVITY}

\section{Creation as a collective process and the creation of cultural and economic value: the role of intermediaries}

In the first place, we must clarify that the notion of intermediary is totally inappropriate for the cultural sector, given that the creation phase cannot be clearly separated from the production or distribution phase, and symbolic capital or value can be produced in all segments of the cooperation chain as well as collectively by the whole cultural field (Bourdieu, 2008). The creation process requires the involvement of several professions considered as technical or managerial, but which play a very important micro-interactive role in the process itself, and in the configuration of the final product (Becker, 1984; Peterson, 1997).

Numerous sociologists have relativized the notion of author in cultural fields, pointing out that it is an ideological construction based on the romantic ideology of artistic genius (Williams, 1994, Williams, 2001). Some authors have drawn a parallel between the depiction of the artist, like Van Gogh — for instance whose life was characterized by turbulence and social isolation, and the stories of the Catholic saints' lives and their martyrdom. And that, in fact, the accounts of Van Gogh portraying him as an artist who was cut off from the art market, actually underestimate the role played by the numerous intermediaries in constructing value and success posthumously (Heinich, 1992). We should also point out that the particular case of this artist is actually an exception regarding the pathological nature of his personality, rather than constituting a common trait, as can be observed by 
considering the life of other great artists such as Picasso (Franck, 2003). In this respect, Picasso maintained many close relationships with his dealers, Vollard and Khanweiler, within a context of exchange and negotiation on the way of presenting (and, therefore, valorizing) his work, as well as on controlling the sale of his pictures and the corresponding economic conditions (Assouline, 1989).

One of the most interesting contributions to this field is made by Howard Becker, who adopts an interactionist view on the world of art (and is, therefore, relativistic about the notion of authorship). This leads him to reassess the figure of the artist in terms of how it fits into the cooperation chain intrinsic to artistic work (Becker, 1984). According to his perspective, art is a collective activity involving a host of intermediaries, in addition to those considered as creators. With respect to artists who do not find the right intermediaries for their works, they can look for other outlets, but this will also change the final result and open up new perspectives. In addition, there are operating rules in the world of art and a division of labour that is arbitrary and, although difficult to change, constantly evolving. For example, in the field of music there has always been conflict regarding the notion of authorship, although since the music sphere became consolidated as an autonomous cultural sphere in the nineteenth century the tendency is to consider the composer as the author and the musician-performer as an intermediary. Notwithstanding, various musical trends such as jazz or contemporary music call this convention into question. Nor is there a clear division between author and intermediary in fields like conceptual art or large sculptures, in which the artist does not perform the work, or in the film industry, where works are produced collectively and there may be several authors and important technical contributions (scriptwriter, director of photography, soundtrack composer, etc.).

Intermediaries also play a very important role in the creation of cultural value and reputation, being products, such as visual works of art, without a value defined a priori by the material they are made of, or by the man-hours required to produce them (Becker, 1994; Moulin, 1992). Then again, in the case of works targeting the most avant-garde sector, they lack a previously constituted public or demand (Bourdieu, 2002). Also, in the following stages of the creative career, the economic value of the marketconstructed economic value of works cannot be defined mid-term (Becker, 1994). Critics of cultural intermediation argue that their action is based on creating an artificial scarcity and on contributing to reproduce a shortage of demand (Lessig, 2005). However, studies of cultural professions in which an artificial demand has been created based on public resources show that the works of artists that are not valued by intermediaries end up having the value of the material from which they are made, i.e., a value close to zero, and they are scarcely professionalized in the artistic field (Menger, 2009).

Thus, since the advent of the critic-dealer system in the late nineteenth century, which replaced the academic mechanisms of admission to and development of the artistic career, the intermediaries have played the following basic roles: a) on the one hand, they act as gatekeepers of the artistic worlds to reduce the excess supply, which is one of the characteristics of the creative professions (Menger, 1999); b) on the other hand, intermediaries can take on different roles within artistic markets: first, the initial promotion, career development at the regional or state level and, finally, institutional consecration and projection in the global market. Each of these career stages will correspond to a type of intermediary with different competences and economic capacity (Moulin, 1983; Moulin and Cardinal, 2012); c) these intermediaries, on being situated in the realm of the artistic market or a segment thereof, orient the consumer towards a type of offer. Such orientation can be interpreted as a structural homology, as a reflection of the hierarchies in the artistic field toward the social field (Bourdieu, 1991) or, in a less deterministic way, as a mediation between the artistic worlds and the formation of amateur communities able to develop criteria and experiences in order to create taste and value (Hennion, 2004). 
Some authors extend the notion of creativity and affirm that not only are the authors creative but also the intermediaries; thus one may speak of creative management (Bilton, 2007). Without reaching this extreme, which seems inappropriate given its combination of clearly differentiable notions, such as cultural creativity and innovation in management, we understand that intermediaries play a fundamental role in the cultural system by providing creators visibility. For example, it is well known that art dealers establish the artistic system, as in the case of Daniel Henry Kahnweiler, an art dealer who contributed decisively to the concept of the cubist style (Assouline, 1989). To do so, he resorted to his social networks, art fairs and their conformation in urban art districts thereby attracting the attention of art collectors and enthusiasts (Rius, 2012). A similar role can be found for producers in the audiovisual and record sectors, who also play an essential role in generating new styles and musical labels, which provide greater visibility and connection with music consumers (Negus, 2002).

But perhaps we can find the most consistent example in the figure of the businessman Serguéi Diáguilev, who formed the company of Russian Ballets between 1909 and 1929 (the latter being the year of his death). The company was the hub of the vanguards in the arenas of music, visual arts and, of course, choreography. Diáguilev's death brought with it the disappearance of a company that had recruited the most important assets of musical creation for the previous two decades. These included Musorgsky, Tchaikovsky, Borodin, Prokofiev, Stravinsky, Ravel, Debussy, Satie, Fauré and Falla. In the field of the visual arts, painters who collaborated in the company's productions included Picasso, Matisse and Braque, to name but a few. But it is undoubtedly within the choreographic field that Diáguilev's entrepreneurial project bears even greater importance and significance, with the collaboration of choreographers who represent a benchmark in the history of much of $20^{\text {th }}$ century choreography (Fokine, Petipa, Massine and Balanchine), providing a company model that tends to be mimicked by both classical ballet and contemporary dance companies, and even by flamenco and Spanish dance throughout the $20^{\text {th }}$ century.

\section{Creators and intermediaries: an interdependent system}

Based on renowned authors and comparative research, the previous sections have emphasised the importance of social interactions in cultural creation and intermediation processes. However, in view of the processes that predict the beneficial effects of the dismantling of the cultural professions and industries as we know them today, we must consider that the cultural sphere is an interdependent system. Several authors have considered the appropriateness of analysing the cultural realm as a system of relationships involving different agents that are mutually determined (Hirsch, 1972).

Finally, some authors have perceived a growing awareness in the cultural sectors of the overlapping of the commercial, entertainment and the informal art sectors (Cherbo and Wyszomirski, 2000). It would be easy to find examples of actors simultaneously working in television series, which provide support, and in community theatre or artistic education that provide regular work and income, as well as in riskier projects related to experimental theatre that provide an opportunity for learning and cultural capital within their profession (Menger, 1997). Thus, from this viewpoint, the crisis or disappearance of audiovisual companies also indirectly affects community and educational projects as well as experimental theatre. Therefore, the digital transition and drop in revenues of a segment not only affects this segment but also the entire cultural system, with the consequent decline in the future prospects of developing innovative projects. Furthermore, we must also remember that one of the intermediaries' missions is to support the creator during the process of shaping a public that understands and appreciates their new creations, and generating the demand that will generate sufficient resources for the artist to be able to dedicate himself to his work professionally (Becker, 2008). In the absence of intermediation, the professionalization process experienced since the nineteenth century may be reversed, transforming cultural activities into parasitic activities, dependent on other professional activities such as teaching. However, part-time dedication decisively reduces the ability to undertake intensive projects in short-term interactions and long-term projects, as well as the generation of cultural movements that require 
important investments in time and resources, like those facilitated by intermediaries in the form of salaries or up-front payment for works and their copyright (Levine, 2013).

In addition, intermediaries play a decisive role in establishing themselves as representatives of the cultural sector as a whole. Cultural intermediaries have a long tradition of professional and trade-union organization, especially in the performing arts and audiovisual sectors (also in the visual arts, albeit to a lesser extent), even in countries whose political culture is not prone to trade union movements, such as the United States (Martel, 2011) $)^{1}$.

\section{Creators, intermediaries and creation:} an interdependent system

So far we have established that, far from being an individual activity carried out in isolation, creation is largely carried out within the framework of interaction structures and processes, which call for cooperation with other agents, i.e., intermediaries. This goes beyond simple service provision as it involves a substantive and valorising collaboration (and, therefore, content-forming) of creation. However, the sociological determinants of creativity do not end here, but, from a more meso- and macro-sociological perspective, we should also point out that creation takes place in organizations and social systems which, as Crozier and Friedman (1982) point out, condition - but do not determine - the performance of the agents involved.

Even so, sociological analyses have shown that there is a relationship between the determinants of the cultural system and the capacity of creation

\footnotetext{
1 The defence of the disappearance of cultural intermediaries by political positions based on progressive or left-wing political positions is largely paradoxical in that it also affects the ability of wage earners and professionals to formulate collective interests within the cultural sector and compete with large production companies and technological multinationals. In fact, it should be understood that those defending the disappearance of cultural intermediaries form part of the libertarian and neoliberal ideology of the Californian school (Barbrook and Cameron, 1996)
}

and innovation of cultural agents. Thus, some authors have analysed the changes in the cultural system as a product of various internal factors of the cultural field and, at the same time, drivers of fundamental transformations in the mode of creating. For example, this was the case of the transition from the academic artistic system to the market-driven system in the nineteenth century, caused not by a stylistic development but rather by the inability of the academic structure to provide an artistic career to a growing artistic population, or to satisfy the cultural demand of the urban population (White, 1993). Since then, the market-driven system constitutes a mechanism in which three independent but articulated actors play (creator, intermediaryentrepreneur and critic). This greatly boosted artistic creativity, first in the form of avant-gardes organized in the early $20^{\text {th }}$ century (Moulin, 1983) until debilitating around the 1980s (Crane, 1987). Currently, although some authors predicted its dissolution, we are in fact witnessing a globalization process of the artistic sectors, especially visual arts, in which agents of international reach (international fairs, auction houses, transnational museums) are fostering new interventions and constructions of artistic reputations (Quemin, 2013).

From the perspective of the production of Peterson's culture (1982), which establishes five factors that influence creativity (legislation, technology, market, organizational structure and career structures), the cultural system can be found in two extreme situations: a) from the 1930s to the 1960s, the existence of an intermediation monopoly and stability or repetition (musical sector before 1959), or b) since the 1960s, the emergence of competition between intermediaries (new radio stations, record companies and independent music agents) generating a context of fierce innovation (with an explosion of creativity and styles in rock and pop music). However, Peterson himself acknowledges that since the 1980s there has been growing articulation between large conglomerates and independent companies, in a process that shapes a competitive scenario with lower creativity 
(Peterson and Anand, 2004). This scenario is also altered by the emergence of large technology companies and the lax internet regulation regarding copyright (Levine, 2013), which, however, has not paralyzed the expansion of blockbuster cinema and, at the same time, the quality television series in the USA. (Martel, 2011)

Then again, some authors have focused their analysis of this cultural system on its urban dimension, engaged in the concentration in big cities (RiusUlldemolins, 2014) and in spatial configurations like the creation of cultural clusters, encompassing the concentration of cultural and creative enterprises, cultural consumption, cultural institutions and creative scenes (Zarlenga, Rius-Ulldemolins and Rodríguez Morató, 2013). These studies can be divided into two groups: first, research focusing on the dynamics of creative clusters (Moomas, 2004; J. Rius-Ulldemolins, 2014). These authors analyse the reasons for the concentration of the creators from variables such as the type of organization (the logic of the industrial district in the context of the post-Fordism economy), the particularities of the cultural sector (the concentration of demand, (cultural appraisal of cultural innovation and crossdisciplinary pollinization). Second, other authors analyse how economic growth is affected by the concentration of the creative class and their economic and social efficiency (Florida, 2005a; Markusen and Schrock, 2006; Scott, 2007). However, we have yet to demonstrate the effectiveness of cultural clusters (J. Rius-Ulldemolins and Zarlenga, 2014) in terms of their cultural creativity beyond the economic and professional benefits (J. Rius-Ulldemolins, 2014) or their ability to attract public and media attention to phenomena inherent to cultural consumerism (Currid and Williams, 2010; Molotch and Treskon, 2009). Anyhow, cybertopic notions such as «crosspollination» (Moulier-Boutang, 2010) that foretell interdisciplinary cooperation and a merging of the boundaries between culture, economy and society, included by some authors in this urban framework (Currid, 2007), have not been demonstrated in the cultural sphere, despite representing a beautiful metaphor. Thus they are only applicable to certain cultural movements that, as Collins analyses, have been driven by coalitions and tightly woven networks of few players rather than by extensive and decentralized networks (Collins and Guillen, 2012).

\section{CREATIVITY AND CULTURAL POLICY: USES AND ABUSES OF A PARADIGM}

\section{The emergence of the discourse on creativity and innovation in cultural politics}

In the post-Fordism capitalist economy, where the role of knowledge constitutes a key element in productivity and competitiveness, not only in the private sector but also in the public sector (nations, regions, cities), discourses of innovation and creativity shape and reinforce the processes of cultural change in our society.

From a sociological perspective, innovation and creativity take on a symbolic dimension that traverse the institutional conglomerate of society, forming a set of roles, norms and values that give meaning to social practices. An example of this is the university, an institution dating back centuries, whose mission (strategic plans) and vision and objectives are influenced due to the incorporation of the values (and practices associated with those values) of innovation and creativity. This binomial acts as an axis of change in this institution, the result of a process of mimetic isomorphism (DiMaggio, 1991), as evident by analysis of the strategic plans of the public universities (Palomares Montero, García Aracil and Castro Martínez, 2012). Thus, content analysis of strategic plans shows that innovation is the first indicator of results and impacts (absolute numbers of all public universities) of the knowledge transfer mission, while the scientific park (linked to technological innovation) is the fifth indicator in the dimension of resources and activities of this mission. Likewise, creativity is also cited as an indicator of the results and impact of the university's research mission. An empirical comparison of the strategic 
plans of Spanish universities highlights the mimetic isomorphism-driven influence of the discourses of innovation and creativity on the symbolic elements of the Spanish university (mission and values) and, consequently, their plausible effects on institutional practices. Here we obviate other types of coercive isomorphism such as incorporation into the European Higher Education Area and the European Research Area or the establishment of the Higher Education Space common to all advanced countries.

Focusing now on the field of art, the institutionalization process has been experienced due to the emergence of cultural policies in developed countries (especially in Western Europe) as of the second half of the $20^{\text {th }}$ century. Artistic organizations are organized institutionally according to the processes of sedimentation historically articulated through national, regional and local cultural policies based on their orientation (cultural democratization, cultural democracy, etc.).

In the context of the Fordism economy, the paradigm of the creative city (Landry and Bianchini, 1995) has become a key element in territorial development (Scott, 2001; Scott, 2010). Mechanisms for spreading the use of large events as catalysts of urban development include the construction of flagship museums (Bianchini, 1993b), the generation of large events (Bianchini, 1993a; García, 2008) or the creation of cultural clusters. Based on these actions, a new model of cultural policy has been developed, which embodies the desire to unite urban change, economic development and social transformation (Connolly, 2011). Thus, since the 1980s cultural policy has been conceived as an engine of city economy and as a lever for the regeneration of urban centres and for metropolitan planning and development (Landry and Bianchini, 1995).

Likewise, a tendency arose to instrumentalize cultural policy for the purposes of other public policy agendas (Belfiore, 2004; Gray, 2008). Within this context, there is a change in the discourses on cultural policy objectives, which become legitimized as new ways of promoting social inclusion while simultaneously acting as an engine of urban economic development within the framework of the new knowledge economy (Connolly, 2011; Menger, 2010). In this context, the organizational dimension of cultural policy is transformed under the principles of New Public Management, with publicly funded cultural organizations becoming agencies and instruments to achieve these new objectives (Rius-Ulldemolins and Rubio, 2013).

The beginning of the 1990s witnessed a new movement that included urban planners, nongovernmental organizations and administrative agencies, who understood culture as a central element of urban regeneration, economic development and social inclusion (García 2004). This kind of strategy represents a split from past practises, whereby some administrations conceive and use cultural products to create a national identity at a distance through elements of so-called high culture, to guide cultural democratization or to integrate different cultural expressions, according to the paradigm of cultural democracy (Urfalino, 1996). Nowadays culture is understood and instrumentalized in a very different way, as a product or a service that can provide a direct economic benefit to a city, either through strategies linked to the construction of the image of a city as a tourist attraction (branding), as an industry or a sector for economic development (creative industries).

The strategic use of culture brings together geographers, urbanists, economists and policymakers to develop a new type of urban planning that includes culture as a central element. Thus, we move from urban planning to cultural planning in cities (Evans 2001). A series of actions are deployed by means of various plans, competitiveness strategies between cities (such as European Cultural Capitals) or cultural mega-events (e.g., Universal Forum of Cultures 2004 held in Barcelona) aimed at promoting the economic development and regeneration of urban centres through creative industries and tourism (García 2004). 


\section{Instrumentalization of culture under the creative city paradigm}

The growing instrumentalization of culture for economic, urban and social purposes is based on an a priori assumption that culture generates positive impacts and effects; indeed since the 1980s this discourse has come to replace traditional legitimations based on cultural value (Belfiore and Bennett, 2008; Belfiore and Bennett, 2007). This axiom, however, has rarely been based on empirical evidence, but rather on the discourse of political leaders in alliance with private consulting agencies (Belfiore, 2002; Belfiore, 2004). This programmatic and discursive transformation in cultural policy has not taken place, unlike other changes, in the deliberative areas of culture such as art councils or culture ministries, but mainly in the political and economic elites. Indeed, since their advent in the mid-eighties, think-tanks and cultural consultants have become established as processors and legitimizers of new cultural policies that, in tune with neoliberalism and its entrepreneurial drift, encourage local governments to use culture as a way of solving social problems without increasing social expenditure or rethinking economic policies (Miles, 2005; Mooney, 2004).

These consultancies, created in the heat of the new labour movement in the UK, coincide with the redirection of cultural policies towards a policy supporting the so-called creative industries and promoting creative enterprises and cultural management (Bilton, 2007; Schlesinger, 2013). Today, in most countries these discourses are disseminated through the academic media and international private consultancies, associating the idea of culture to an instrument of economic development and entrepreneurship that, according to this view, leads to cultural and artistic creation (Cunningham, 2009)2 . Regarding entrepreneurship, this has become an allencompassing ideology of the cultural sector (Rowan,

2 Spain, and especially Barcelona, is one of the places in Europe where this discourse and its way of operating has enjoyed greater success, and has become one of the elements of the so-called Barcelona model of cultural policy (Degen and García, 2012; Sánchez, Rius-Ulldemolins and Zarlenga, 2013).
2010). It takes on the instrumental role in an entire economic sector, or economic development vector (the so-called creative industries) and further dismantles the autonomy of the artistic sphere by converting it into a common psychological attitude encompassing a huge diversity and heterogeneity of human tasks, sidelined from its humanistic and disciplinary tradition, and dominated by consultants and think tanks who redefine it (Fullerton and Ettema, 2014). Consequently there is confusion between cultural policies and policies for economic promotion, or between cultural activities and skill and ability-training activities (Jones, 2010).

Another dominant international discourse is that of the creative city, pioneered by Landry and Bianchini (1995) and developed by Richard Florida with the belief that the creative classes can transform the urban economy (Florida, 2005b). This idea has been criticized for its theoretical inconsistency in the use of the concept of social class, and its gentrification effects on the cities where it has been implemented (Peck, 2005; Pratt, 2008). In spite of such criticism, this discourse has achieved noteworthy prestige and diffusion in the Spanish State, where successive meetings of governors, consultants and cultural agents have been held to exchange experiences and, in general, promote this paradigm ( $c f$. Manito Lorite, 2010).

Furthermore, the model of creative cities fits well in the context of Spain due to the cultural protagonism of cities, the importance of tourism and the trend towards the construction of oversized cultural infrastructures, legitimating state, regional or local political power ( Rius-Ulldemolins, 2014; Rubio and Rius, 2012). In some cities, this paradigm of the creative city has entailed expensive cultural events, which have not generated clear social or economic profits apart from those gained by construction companies and real estate speculators (Majoor, 2011). Likewise, this ideology promoted and legitimized by consultancies has also led to the construction of large cultural infrastructures that have often been poorly designed with respect to their future uses and local cultural needs, such as Valencia's Ciutat de les Arts (City of Arts), Santiago de Compostela's Cidade da Cultura (City of Culture), or 
the costly enlargement of infrastructures in Madrid, such as the Reina Sofía Museum (Hernàndez i Martí and Rodrigo, 2012; Lage, Losada and Gómez, 2012; Rius Ulldemolins, Rodríguez Morató and Martinez Illa, 2012). Not only do these infrastructures represent huge investment spending and a mortgage on future budgets due to their high maintenance costs, but they also represent a huge cost to opportunity by investing all energies of the cultural sector in promoting them (or criticizing them), neglecting efforts to weave real structured systems for cultural policy, or create truly sustainable spaces for cultural participation (Sánchez et al., 2013).

All these negative effects were predictable in view of the dearth in planning based on objective cultural needs, and the disregard for social and cultural sustainability (Kagan and Hahn, 2011; Martinez and Rius, 2010); however, scant criticism has been heard from the social science sector against these actions, which have turned cultural policies into subsidiaries of the construction of international urban brands, so-called place branding (Pike, 2011; Rius Ulldemolins and Zamorano, 2014).

Indeed, it is the area of urban studies that has raised the most radical criticisms of this model, pointing out its commercial effects on urban spaces and the dismantling of community relations (Balibrea, 2004; Delgado, 2008). However, this criticism has not managed to influence the planning and decision-making processes implemented in the public management of culture. Evidence of this is that until 2010, when Spain was teetering on the edge of the economic, political and social abyss, many consultants and academics continued to promote projects of creative cities, clusters of cultural industries requiring huge investments on the basis of hypothetical future returns.

\section{Abuses of the paradigm of the creative city: the "cultural white elephants "}

One of the consequences of the creative city paradigm and its decision for follow the logic of «opportunity», heedless of planning anchored in the response to a budding welfare state, is the generation of «cultural white elephants». The expression white elephant, common in both Spanish and English, refers to infrastructures or constructions whose maintenance costs exceed the benefits they provide, or infrastructures/constructions that profit others but only cause problems for the owner, especially if owned by the public administration. Thus, in cultural policy, we classify as white elephants those cultural projects, large infrastructures in particular but also major cultural events or clusters, that have been the focus of public cultural action for a long time, i.e., from the mid-nineties to the end of 2000 (Coinciding with economic expansion) and which have since become a problem and remain the cultural symbol of that era. Examples of white elephants can be found in Spain, although other examples and cases can be witnessed worldwide, especially in countries with a recent urban and cultural boom that lack developed cultural networks and infrastructures.

Although the term white elephants has been used in some articles, such as O'Connor (2012), its conceptualization has not been developed. From our point of view, as previously outlined (Rius-Ulldemolins, Hernández i Martí and Torres Pérez, 2015) we are dealing with: a) A development of cultural policy characteristic of the model adopted by cities that have opted for global culture, without endeavouring to create a balance with more sustainable elements or a link to the local culture (Bianchini, 1993b; Bloomfield and Bianchini, 2004) and who have found in the paradigm of the creative city and the creative class a justification for undertaking major projects without previous planning or assessment of the citizens' needs (Novy and Colomb, 2013; Peck, 2005). b) They may be large cultural facilities, major events or, in more recent developments, cultural facilities and service districts (arts, music or theatre cities) or cultural and creative clusters separated from the urban fabric such as science parks. c) These projects engender buildings and/or public spaces that quickly lose the utility for which they were built (either because the great event for which they were designed is over or because the actual use differs from the intended use) creating what Augé (2003) calls modern ruins, underused and falling into decay. d) White elephants are the product of a stratagem aiming to fascinate the public (in this case, local and global citizens), by 
generating euphoria which distracts from the associated urban transformation process and justifies the negative effects it has on the excluded sectors (segregation and gentrification) in a discourse mixing the legitimacy of culture and the supposed future benefits of these actions with an instrumentalist discourse of culture, without demonstrating the final social impact (E. Belfiore and Bennett, 2007). They are not, however, the product of a contract or program previously drawn up between government and an agency in charge of project management (Rius-Ulldemolins and Rubio, 2013). Finally, its mission is not defined until after the project has commenced, based on the function they can provide rather than on the cultural needs detected through prior consumer studies or cultural participation. e) In this type of action, calculating the costs of its social uses is overlooked in favour of alleged indirect impacts and the intangible benefit of the city brand. Albeit in the short term, the white elephant stirs up fascination in the local population and has an impact in the global mass media; however, the fact it becomes an expensive infrastructure to maintain, impossible to monetize and difficult to upkeep, can create an image of squandering and decadence in the mid and long term. Sometimes, corruption occurs during its inception and development, calling into question the legitimacy of spending in the cultural sector. $f$ ) Finally, white elephants generate a great problem of sustainability and amortization, as they deplete present and future resources of the local cultural system and, furthermore, are often difficult to reuse for uses other than those for which they were conceived. White elephants, therefore, represent a serious medium and long-term debt for cultural policy, and a challenge to find new functionalities that add value to the system of local, regional or national cultural policy.

\section{FINAL NOTES}

The works by Bourdieu, Collins and Menger have been analysed in this article to offer a theoretical overview of the vision of the sociology of creativity. These three significant authors represent different currents of theoretical traditions and approaches, although there are common denominators in their analysis. These commonalities include their questioning of the romantic conception of creativity, as we have stated previously, or the assessment of the role of social conditions that favour creativity, and forms of social valorization leading to certain actions being considered as creative while others are cast-off. Indeed, it is here that we find the differences in the approaches analysed. In the case of Bourdieu, it is not possible to obtain creativity outside the cultural fields and without the previous socialization of the habitus in the dynamics of the cultural field and its history. In the case of Collins, creativity is also reduced from a microsociological vision to small groups and to the role of face-toface relationships and the rituals of everyday life in small groups. Menger, however, focuses on how the institutions themselves generate constant mechanisms of differentiation and distinction, focusing reputation (and creativity) on an elite.

The rise of new technologies inescapably facilitates access to cultural creation and undermines the role of intermediaries. This process, according to cyberutopian discourse, entails the absence of frontiers restricting entry to the cultural sector and, therefore, a flourishing of creativity in a world where copyassociated costs are close to zero margin cost. This is celebrated by the discourse of free creativity made possible by access to technology. Likewise, the discourse of the disappearance of professional intermediaries is interwoven with the discourse that technology makes us all creators and intermediaries at once. However this discourse progressively collides with the evidence of the dysfunctions of the process of digitization of the cultural system. In this respect, this excessively optimistic discourse can and should be juxtaposed with the contributions made by the sociology of culture, in relation to authors, intermediaries and the cultural system. Thus, cultural digitization enthusiasts, focusing their argument on producer-consumer opposition, where the power of producers is relativized in favour of consumers, tend to overlook the social configurations that promote creativity and favour recognition, which is hard to adapt to the utopian vision of virtual communities. In our opinion, a proper 
understanding of the specific logic of cultural fields escapes these digital theorists because they disregard the role of cultural intermediaries in the process of cultural production, distribution and valuation, and their interpretive proposals ignore the structural traits characterizing specialized cultural production, which have been explored in the field of sociology of culture by diverse authors such as Bourdieu (2002), Collins (2009), Menger (2009), Becker (2008) or DiMaggio (1991).

Furthermore, creativity-based projects are highly effective tools for the redefinition of urban spaces and, undoubtedly, help attract the public. Creative clusters can also facilitate local and regional economic promotion, but if they fail to develop a structured field of creative players or circle of creators focusing on specific points of cultural attention, there is actually little cultural productivity. Without sectoral articulation or more intense interaction, their substantive benefits in cultural terms are somewhat mediocre. In these two cases, analysis of the virtues of creative clustering leads us to identify them as an empty institutional discourse, similar to the phenomenon of bullshitting (affirmations lacking an empirical basis but repeated time and again) identified by Franckfurt (2005), whose main purpose is to legitimize public investments or urban decisions.

Observation of the Spanish State discloses widespread examples of cultural white elephants. These include, but are not limited to districts housing cultural facilities such as the Ciutat de les Arts in Valencia or the Cidade da Cultura in Santiago de Compostela; mega-events such as the Fòrum de les Cultures in Barcelona, or clusters of cultural industries like the Ciutat de la Llum in Alicante or the Centro de las Artes in Alcorcón. All these are examples of projects developed under the rhetoric of creativity alleging benefits for local development and innovation, but which lack realistic planning or diagnosis of the socio-cultural impacts and costs or mid- and long-term sustainability. Cases like these embody the expression of a discourse on creativity that has turned a deaf ear to citizen opposition, and legitimized projects with high investment and inflated maintenance costs, on the one hand and, on the other, scarce (or even null) economic yields or value for the cultural sector or citizens as a whole.

\section{BIBLIOGRAPHIC REFERENCES}

Alonso, L. E. and Fernández Rodríguez, C. (2013). Los discursos del presente. Un análisis de los imaginarios sociales contemporáneos. Madrid: Siglo xxi.

Assouline, P. (1989). L'homme de l'art. D.-H.Kahnweiler (1884-1979). París: Gallimard.

Augé, M. (2003). El tiempo en ruinas. Barcelona: Gedisa.

Balibrea, M. P. (2004). Barcelona: Del modelo a la marca. In J. Carrillo, I. Estella Noriega and L. García-Merás (eds.), Desacuerdos 3. Sobre arte, políticas y esfera pública en el estado español (pp. 261-271). Barcelona: Arteleku — MACBA — Universidad Internacional de Andalucía.

Barbrook, R. and Cameron, A. (1996). The californian ideology. Science as culture. Science as Culture, 26(1), 44-72.

Becker, H. (1994). La confusion des valeurs. In P. Menger and J. Passeron (eds.), L'art de la recherche, Essais en l'honneur de Raymonde Moulin (pp. 24-39). París: La Documentation française.

Becker, H. S. (1984). Art worlds. Berkeley: University of California Press.

Becker, H. S. (2008). Los mundos del arte. Sociología del trabajo artístico. Buenos Aires: Universidad Nacional de Quilmes. Belfiore, E. and Bennett, O. (2008). The social impact of the arts: An intellectual history. Basingtoke: Palgrave/Macmillan. Belfiore, E. (2002). Art as a means of alleviating social exclusion: Does it really work? A critique of instrumental cultural policies and social impact studies in the UK. International Journal of Cultural Policy, 8(1), 91-106.

Belfiore, E. (2004). Auditing culture. The subsidised cultural sector in the new public management. International Journal of Cultural Policy, 10(2), 183-202.

Belfiore, E. and Bennett, O. (2007). Rethinking the social impact of the arts. International Journal of Cultural Policy, 13(2), 135-151. doi: : 10.1080/10286630701342741

Bianchini, F. (1993a). Remaking european cities: The role of cultural policies. In F. Bianchini, and M. Parkinson (eds.), Cultural policy and urban regeneration: The West European experience (pp. 1-19). Manchester: Manchester University Press. 
Bianchini, F. (1993b). Urban cultural policy in Britain and Europe: Towards cultural planning. London: Institute for Cultural Policy Studies.

Bilton, C. (2007). Management and creativity: From creative industries to creative management. Malden, MA; Oxford: Blackwell Pub. Bloomfield, J. and Bianchini, F. (2004). Planning for intercultural city. London: Comedia.

Bohm, D. (2006). On creativity. New York: Routledge.

Bourdieu, P. (2008). Homo academicus. Madrid: Siglo XXI.

Bourdieu, P. (1991). La distinción: Criterios y bases sociales del gusto. Madrid: Taurus.

Bourdieu, P. (2002). Las reglas del arte: Génesis y estructura del campo literario (3 ${ }^{\text {rd }}$ ed.). Barcelona: Anagrama.

Bourdieu, P. (2008). Cuestiones de sociología. Madrid: Akal. Básica de Bolsillo.

Cherbo, J. M. and Wyszomirski, M. J. (2000). The public life of the arts in America. New Brunswick N. J.: Rutgers University Press.

Collins, R. (1987). A micro-macro theory of intellectual creativity: The case of German idealist philosophy. Sociological Theory, 5(1), 47-69.

Collins, R. (2005). Sociología de las filosofías: Una teoría global del cambio intelectual. Barcelona: Hacer.

Collins, R. (2009). Cadenas de rituales de interacción. Barcelona: Anthropos.

Collins, R. and Guillen, M. F. (2012). Mutual halo effects in cultural production: The case of modernist architecture. Theory and Society, 41(6), 527-556.

Connolly, M. G. (2011). The 'Liverpool model(s)': Cultural planning, Liverpool and Capital of Culture 2008. International Journal of Cultural Policy, 1-20. doi: 10.1080/10286632.2011.638982

Crane, D. (1987). The transformation of the avant-garde: The New York art world,1940-1985. Chicago: The University of Chicago Press.

Crozier, M. and Friedberg, E. (1982). L'acteur et le système : Les contraintes de l'action collective. París: Éditions du Seuil.

Csikszentmihalyi, M. (1988). Creatividad: El fluir y la psicología del descubrimiento y la invención. Barcelona: Paidós.

Cunningham, S. (2009). Trojan horse or Rorschach blot? creative industries discourse around the world. International Journal of Cultural Policy, 15(4), 375-386. doi: 10.1080/10286630902977501

Currid, E. (2007). The Warhol economy: How fashion, art, and music drive New York city Princeton University Press.

Currid, E. and Williams, S. (2010). The geography of buzz: Art, culture and the social milieu in Los Angeles and New York. Journal of Economic Geography, 10(3), 423-451.

Degen, M. and García, M. (2012). The transformation of the Barcelona model?: An analysis of culture, urban regeneration and governance. International Journal of Urban and Regional Research, 36(5), 1022-1038.

Delgado, M. (2008). La artistización de las políticas urbanas. El lugar de la cultura en las dinámicas de reapropiación capitalista de la ciudad. Scripta Nova: Revista Electrónica De Geografía y Ciencias Sociales, 12. Retrieved from http: //www.raco.cat/index.php/ScriptaNova/article/view/115467

DeNora, T. (1995). Beethoven and the construction of genius: Musical politics in Vienna. Los Angeles: University of California Press.

DiMaggio, P. (1991). Social structure, institutions and cultural goods: The case of the United States. In P. Bourdieu and J. Coleman (eds.), Social theory for a changing society (pp. 133-166). Boulder: Westview Press.

Elías, N. (2002). Mozart. Sociología de un genio. Madrid: Ediciones Península.

Florida, R. L. (2005a). Cities and the creative class. London: Routledge.

Florida, R. L. (2005b). Cities and the creative class. London: Routledge.

Franck, D. (2003). Bohemian Paris: Picasso, Modigliani, Matisse, and the birth of modern art. New York: Grove Press.

Frankfurt, H. (2005). On bullshit. Princeton: Princeton University Press.

Fullerton, L. and Ettema, J. (2014). Ways of worldmaking in wikipedia: Reality, legitimacy and collaborative knowledge making. Media, Culture \& Society, 36(2), 183-199. doi: 10.1177/0163443713515739

García, B. (2008). Política cultural y regeneración urbana en las ciudades de europa occidental: Lecciones aprendidas de la experiencia y perspectivas para el futuro. Revista de Investigaciones Políticas y Sociológicas, 7(1), 111-125.

Gray, C. (2008). Instrumental policies: Causes, consequences, museums and galleries. Cultural Trends, 17(4), 209-222. 
Heinich, N. (1992). La gloire de Van Gogh. Essai d'anthropologie de l'admiration. París: Éditions de Minuit.

Hennion, A. (2004). Une sociologie des attachements. D'une sociologie de la culture à una pragmatique de l'amateur. Sociétés, 85(3), 9-24.

Hernàndez i Martí, G. and Albert Rodrigo, M. (2012). La dinámica general de la política cultural en el País Valenciano: Posiciones, discursos y prácticas de los actores culturales valencianos. Revista de Investigaciones Políticas y Sociológicas, 11(3), 89-114.

Hirsch, P. M. (1972). Processing fads and fashions: An organization-set analysis of cultural industry systems. American Journal of Sociology, 77(4), 639-659. Retrieved from http: //www.jstor.org/stable/2776751

Joas, H. (1996). The Creativity of Action. Cambridge: Polity press.

Jones, S. (2010). Culture Shock. London: Demos.

Kagan, S. and Hahn, J. (2011). Creative cities and (un)sustainability: From creative class to sustainable creative cities. Culture and Local Governance, 3: 1-2, 11-27.

Lage, X., Losada, A. and Gómez, M. (2012). La política cultural en la comunidad autónoma gallega: De la dependencia a la autonomía. Revista de Investigaciones Políticas y Sociológicas, 11(3), 115-148.

Landry, C. and Bianchini, F. (1995). The creative city. London: Demos.

Lessig, L. (2005). Por una cultura libre: Cómo los grandes grupos de comunicación utilizan la tecnología y la ley para clausurar la cultura y controlar la creatividad. Madrid: Traficantes de Sueños. Retrieved from http: //www.elastico.net/archives/

Levine, R. (2013). Parásitos: Cómo los oportunistas digitales están destruyendo el negocio de la cultura. Barcelona: Ariel.

Majoor, S. (2011). Framing large-scale projects: Barcelona Forum and the challenge of balancing local and global needs. Journal of Planning Education and Research, 31(2), 143-156. doi: 10.1177/0739456X11402694

Manito Lorite, F. (ed.). (2010). Ciudades creativas. Barcelona: Fundación Kreanta.

Runco, M. A. and Albert, R. S. (1999). Creativity research: A historical view. In J. C. Kaufman and R. S. Albert (eds.), The ambridge handbook of creativity (pp. 3-19). Cambridge: CUP.

Markusen, A. and Schrock, G. (2006). The artistic dividend: Urban artistic specialisation and economic development implications. Urban Studies, 43(10), 1661-1686.

Martel, F. (2011). Cultura mainstream: Cómo nacen los fenómenos de masas. Madrid: Taurus.

Martinez, S. and Rius, J. (2010). Cultural planning and community sustainability: The case of the cultural facilities plan of Catalonia (PECCAT 2010-20. Culture and Local Goverment, 3: 1-2, 71-82.

Menger, P. (2009). Le travail créateur. S'accomplir dans l'incertain. París: Gallimard.

Menger, P. (2010). Cultural policies in Europe. from a state to a city-centered perspective on cultural generativity. Tokyo: National Graduate Institute for Policy Studies.

Menger, P. (1997). La profession de comédien : Formations, activités et carrières dans la démultiplication de soi. París: Ministère de la Culture et de la Communication. Département des études et de la prospective.

Menger, P. (1999). Artistic labor markets and careers. Annual Review of Sociology, 25, 541-574. Retrieved from http: //www.jstor.org/stable/223516

Miles, M. (2005). Interruptions: Testing the rhetoric of culturally led urban development. Urban Studies, 42(5-6), 889-911. doi: 10.1080/00420980500107375

Misztal, B. A. (2009). Intellectuals and the public good. Creativity and civil courage,. Cambridge: CUP.

Molotch, H. and Treskon, M. (2009). Changing art: Soho, Chelsea and the dynamic geography of galleries in New York City. International Journal of Urban and Regional Research, 33(2), 517-541.

Moomas, H. (2004). Cultural clusters and the post-industrial city: Towards a remapping of urban cultural policy. Urban Studies, 41(3), 507-532.

Mooney, G. (2004). Cultural policy as urban transformation? Critical reflections on Glasgow, European City of Culture 1990. Local Economy, 19(4), 327-340.

Moulier-Boutang, Y. (2010). L'abeille et l'économiste. París: Éditions Carnets Nord.

Moulin, R. (1983). Le marché de l'art en France. París: Éditions de Minuit.

Moulin, R. (1992). L'artiste, l'institution et le marché. París: Flammarion. 
Moulin, R. and Cardinal, M. (2012). El mercado del arte: Mundialización y nuevas tecnologías. Buenos Aires: La Marca.

Negus, K. (2002). The work of cultural intermediaries and the enduring distance between production and consumption. Cultural Studies, 16(4), 501-515.

Novy, J. and Colomb, C. (2013). Struggling for the right to the (creative) city in Berlin and Hamburg: New urban social movements, new "spaces of hope"? International Journal of Urban and Regional Research, 37(5), 1816-1838. doi: 10.1111/j.1468-2427.2012.01115.x

O'Connor, J. and Gu, X. (2012). Creative industry clusters in Shanghai: A success story? International Journal of Cultural Policy, 1-20. doi: 10.1080/10286632.2012.740025

Palomares Montero, D., García Aracil, A. and Castro Martínez, E. (2012). Misiones actuales de las universidades públicas: Una perspectiva sociológica. Vol. 188-753: 171-192. Arbor. Ciencia, Pensamiento y Cultura, 188(753), $171-192$.

Peck, J. (2005). Struggling with the creative class. International Journal of Urban and Regional Research, 29(4), 740-770.

Peterson, R. A. and Anand, N. (2004). The production of culture perspective. Annu. Rev. Sociol, 30, 311-334.

Peterson, R. A. (1982). Five constraints on the production of culture: Law, technology, market, organizational structure and occupational careers*. The Journal of Popular Culture, 16(2), 143-153. doi: 10.1111/j.0022-3840.1982.1451443.x

Peterson, R. A. (1997). Creating country music: Fabricating authenticity. Chicago: University of Chicago Press.

Pike, A. (2011). Brands and branding geographies. Cheltenham; Northampton: Edward Elgar.

Pratt, A. C. (2008). Creative cities: The cultural industries and the creative class. Geografiska Annaler: Series B, Human Geography, 90(2), 107-117. doi: 10.1111/j.1468-0467.2008.00281.x

Quemin, A. (2013). Les stars de l'art contemporain. notoriété et consécration artistiques dans les arts visuels. París: CNRS.

Rius Ulldemolins, J., Rodríguez Morató, A. and Martinez Illa, S. (2012). El sistema de la política cultural en Cataluña: Un proceso inacabado de articulación y racionalización. Revista de Investigaciones Políticas y Sociológicas, 11(3), 173-204.

Rius Ulldemolins, J. and Zamorano, M. M. (2014). Spain's nation branding project Marca España and its cultural policy: The economic and political instrumentalization of a homogeneous and simplified cultural image. International Journal of Cultural Policy, 1-21. doi: 10.1080/10286632.2013.877456

Rius, J. (2012). Gallery districts of Barcelona: The strategic play of art dealers. The Journal of Arts Management, Law and Society, 42(2), 48-62.

Rius-Ulldemolins, J. (2014). La gobernanza y la gestión de las instituciones culturales nacionales: De la oposición entre arte y economía a la articulación entre política cultural y management. Revista Papers, 99(1), 73-95.

Rius-Ulldemolins, J., Hernández i Martí, G. and Torres Pérez, F. (2015). Urban development and cultural policy “white elephants": Barcelona and Valencia. European Planning Studies, 1-21. doi: 10.1080/09654313.2015.1075965

Rius-Ulldemolins, J. and Rubio, A. (2013). The governance of national cultural organisations: Comparative study of performance contracts with the main cultural organisations in England, France and Catalonia. International Journal of Cultural Policy, 19(2), 249-269.

Rius-Ulldemolins, J. and Zarlenga, M. (2014). Industrias, distritos, instituciones y escenas. tipología de clústeres culturales en Barcelona. Revista Española de Sociología, 21, 47-68.

Rius-Ulldemolins, J. (2014). ¿Por qué se concentran los artistas en las grandes ciudades? Factores infraestructurales de localización, estrategias profesionales y dinámicas comunitarias. Revista Española de Investigaciones Sociológicas, 147, 73-88.

Rowan, J. (2010). Emprendizajes en cultura. discursos, instituciones y contradicciones en la empresarialidad cultural. Madrid: Traficantes de Sueños.

Rubio Arostegui, J. A. (2013). La dimensión social de la actividad creativa: Una introducción al enfoque de las ciencias sociales. In: R. Caerols Mateo and J. A. Rubio Arostegui (eds.), La praxis del artista como hacer investigador. Tenerife: Sociedad Latina de Comunicacin Social ed., pp. 61-84).

Rubio, A. and Rius, J. (2012). La modernización de la gestión pública de la cultura. análisis comparado del caso de los equipamientos culturales de las comunidades autónomas de Cataluña y Madrid. Gestión y Análisis de Políticas Públicas, 8, 79-92.

Sánchez, M. V., Rius-Ulldemolins, J. and Zarlenga, M. (2013). ¿Ciudad creativa y ciudad sostenible? Un análisis crítico del modelo Barcelona de políticas culturales. Revista Crítica de Ciências Sociais, 96, 48-57.

Schlesinger, P. (2013). Expertise, the academy and the governance of cultural policy. Media Culture Society, 35(1), $27-35$. 
Scott, A. (2007). Capitalism and urbanization in a new key? The cognitive-cultural dimension. Social Forces, 85(4), 1465-1482.

Urfalino, P. (1996). L'invention de la politique culturelle. París: La Documentation Française.

White, H. C. (1993). Careers and creativity: Social forces in the arts. Colorado: Westview Press.

Williams, R. (1994). Sociología de la cultura (1 $1^{\text {st }}$ reprint). Barcelona: Paidós.

Williams, R. (2001). Cultura y sociedad: 1780-1950. De Coleridge a Orwell. Buenos Aires: Nueva Visión.

Zarlenga, M. I., Rius-Ulldemolins, J. and Rodríguez Morató, A. (2013). Cultural clusters and social interaction dynamics: The case of Barcelona. European Urban and Regional Studies, OnlineFirst, 1-24. doi: 10.1177/0969776413514592.

\section{BIOGRAPHICAL NOTES}

Juan Arturo Rubio Arostegui holds a PhD in Political Science and Sociology (Universidad Complutense de Madrid), a master's degree in Arts Management (music, theatre and dance), and a degree in Philosophy and Education Sciences. He is professor at Universidad Antonio de Nebrija and principal investigator of the Grupo Nebrija de Arte. He researches and lectures in the fields of cultural politics, cultural management, sociology of art, artistic education and research methods in the arts. He has participated in several national R \& D projects and has published books and articles in national and international journals. In 2002 he received the Marcelo Martínez Alcubilla Prize for research on the General State Administration (Ministerio de Administraciones Públicas).

Juan Pecourt is trainee lecturer at the Universitat de València and holds a PhD from the University of Cambridge. Since his PhD award he has undertaken various research works within the cultural and political fields, focusing expressly on the figure of intellectuals and the political press. Product of this research work is the book published by the CIS entitled Los intelectuales y la transición política (Intellectuals and political transition). He is the author of several book chapters and articles dealing with the sociology of culture. Lately his interests have focused on the transformation of the cultural field and the emergence of a new public space made possible by the internet.

Joaquim Rius-Ulldemolins holds a PhD in Sociology from the Universitat Autònoma de Barcelona and the École des Hautes Études en Sciences Sociales. Currently, he is assistant professor in the Department of Sociology and Social Anthropology at the Universitat de València. He has authored several books and articles on the sociology of culture and cultural policy in national and international journals, such as International Journal of Cultural Policy, Urban Studies, European Urban and Regional Studies, REIS and RIS, among others. His research interests focus on the analysis of creative professions and clusters, the role played by cultural institutions in cultural politics or the instrumentalization of culture in urban and territorial branding. 